\title{
Prikazi
}

https://doi.org/10.22210/suvlin.2020.090.05

\section{Patimat Abdulaevna Saidova (2019) Slovar' andalal'skogo dialekta avarskogo jazyka. IJaLI DFIC RAN, ALEF, Mahačkala.}

Саидова П. А. (2019). Словарь андалальского диалекта аварского языка. Под редакцией М. Ш. Халилова. Махачкала: Институт языка, литературы и искусства им. Г. Цадасы Дагестанского федерального исследовательского центра Российской академии наук; АЛЕФ.

U jesen 2019. godine u Mahačkali (Dagestan, Rusija) izišao je iz tiska prvi dijalektni rječnik jednoga od dijalekata avarskoga jezika - andalalskoga. Autorica rječnika Patimat Abdulaevna Saidova, istraživačica leksika avarskih dijalekata, izradila je prvi Dijalektološki rječnik avarskoga jezika (2008). Andalalski je rječnik njezin drugi veliki rad na području istraživanja dijalektnoga leksika avarskoga jezika, u kojem se autorica usredotočila samo na govore svoga zavičaja, Andalala ${ }^{1}$. Rječnik andalalskoga dijalekta avarskoga jezika tiskan je pod uredništvom Madzhida Sh. Khalilova u izdanju Instituta za jezik, književnost i umjetnost»Gamzat Cadasa« te izdavačke kuće ALEF.

PatimatAbdulaevna Saidova preminulaje u kolovozu 2020. Prije samog prikaza njezine knjige htjeli bismo napisati nekoliko riječi o njoj kao čovjeku kako ju pamte kolege. Bila je osoba iznimne skromnosti i profinjenosti, vrlo topla i srdačna, uvijek obzirna, suosjećajna i voljna pomoći svojim suradnicima te odana znanstvenom radu kojim se bavila temeljito i stručno. To je nesebičan rad pokrenut snagom i brigom za očuvanje jezičnoga i kulturnoga blaga vlastitoga naroda i ljubavlju prema znanstvenom istraživanju.

Patimat Saidovaje bila dugogodišnja suradnica Instituta zajezik, književnost i umjetnost »Gamzat Cadasa «2 2 , te je tijekom svoga rada dala značajan doprinos proučavanju gramatike i leksika avarskoga i andijskih jezika - godoberinskoga

1 Danas se područje Andalala ne izdvaja administrativno, andalalska sela ulaze uglavnom u sastav Gunibske regije, koja se nalazi u središnjem dijelu planinskoga Dagestana. Naziv 'Andalal' obuhvaća skupinu naselja-zajednica (općina) i odražava upravno-prostorne, kao i političke te etničke i sub-etničke podjele niza prethodnih stoljeća, koje se kroz jezične, etničke i kulturne značajke čuvaju i danas. Povijesno gledano, u Dagestanu je postojalo nekoliko desetaka tzv. slobodnih društava, odnosno nezavisnih vojno-političkih saveza manjih zajednica s vlastitom samoupravom, a jedan od takvih saveza je bio Andalal. 
(1973, 2006), botlihskoga (Saidova, Abusov 2012) i dr. ${ }^{3}$ Surađivala je u izradi rusko-avarskoga rječnika (Russko-avarskij slovar', 2003) i gramatike suvremenog avarskog jezika (Alekseev i sur. 2014). Najveći doprinos dala je na području leksikologije i leksikografije avarskoga jezika i njegove dijalektne leksikografije. P. A. Saidova je izradila prvi Dijalektološki rječnik avarskoga jezika (2008), koji je ujedno i prvi dijalektološki rječnik jednoga od dagestanskih jezika uopće. Taj je rječnik obuhvatio građu od šest dijalekata i 30 govora. U tijeku dugogodišnjega rada na tom rječniku, a i rječnicima godoberinskoga i botlihskoga jezika, Patimat Saidova je stekla veliko iskustvo u terenskim istraživanjima: "Tijekom rada na dijalektološkom rječniku autorica je više od deset godina svake godine putovala u mjesta stanovanja izvornih govornika u Dagestanu i Sjevernom Azerbajdžanu, nerijetko i u teško pristupačna naselja u planinama. To je bio uistinu nesebičan, revnosan i plemenit rad znanstvenice jezikoslovke« (Magomedov 2008: 11 -12).

To iskustvo bilo je produbljeno i razrađeno u nastavku njezina rada za vrijeme prikupljanja građe iz govora andalalskoga dijalekta po selima Andalala, rada s ispitanicima Andalalcima na proučavanju leksika njihovih mjesnih govora.

P. A. Saidova je rođena i odrasla u području Andalal (naselje Čoh), njezin je materinski jezik bio avarski, preciznije čohski govor andalalskoga dijalekta avarskogajezika.P. A. Saidovaje ne samobilaizvorna govornica svoga materinskoga andalalskog dijalekta, već je izvrsno govorila i avarski standardni jezik. Nakon širih istraživanja dijalekata avarskoga jezika, u svom andalalskom Rječniku približila se najužem području materinskoga jezika, svom zavičajnom govoru.

Avarski jezik ${ }^{4}$ s genetskoga gledišta pripada avarsko-andijskoj podskupini avarsko-ando-cezijske skupine dagestanskih jezika. U avarskom se jeziku izdvajaju sjeverno i južno narječje, s time da se avarski standardni jezik temelji na hunzahskom dijalektu sjevernoga narječja. Sjevernomu narječju, osim hunzahskoga dijalekta, pripadaju još dva dijalekta, istočni i salatavski. 5 Južnomu narječju pripadaju: andalalski, hidski, ancuhski, zakatalski, karahski, kahibski i kusurski dijalekti, dok prijelazan položaj između sjevernoga i južnoga narječja zauzima batluhski dijalekt. ${ }^{6}$

3 U tim je rječnicima Saidova uspjela prikupiti »riječi i izraze koji opisuju današnji način života, povijesnu prošlost, duhovni svijet godoberinaca i botlihca« (Khalilov 2019: 782). Ilustrativna građa obuhvaća veliko mnoštvo frazema, poslovica, uzrečica, dobrih želja, kletvi, vjerovanja (Khalilov 2019: 782).

4 Avarski je među dagestanskim jezicima najveći po broju govornika (oko jednog milijuna ljudi), govore ga, ne samo etnički Avari u užem smislu, veći govornici andijskih i cezijskih jezika, kojima avarski služi kao književni jezik i jezik međuetničke komunikacije.

$5 \quad$ Usp. Alekseev (1998: 204), Madieva (2000: 45).

6 Takav se popis dijalekata južnoga narječja avarskoga jezika navodi prema radu: Alekseev (1998: 204). 
Iako su dijalektološkoj problematici avarskoga jezika posvećeni brojni radovi, nijedan avarski dijalekt do sada nije sustavno leksikografski obrađen.7 U andalalskom rječniku P. A. Saidove, koji je isključivo posvećen jednom dijalektu, rječnički članak pod svakom natuknicom okuplja sustavnu i temeljitu leksikografsku obradu leksema, iznose se podrobni podaci o značenju riječi u tom dijalektu - prijevod na ruski jezik i, u slučaju potrebe, pojašnjenje značenja pa se uključuje opširna ilustrativna građa u obliku sintagma, kolokacija, rečeničnih potvrda, frazema. Kod onih natuknica gdje su prisutne razlike u govorima, navode se sve inačice. Uz to, za svaki leksem se iznose osnovni gramatički podaci. Opseg Rječnika obuhvaća više od 8000 natuknica na približno 500 stranica (str. 44 - 556).

Osim glavnog dijela, tj. samog rječnika, knjiga sadržava niz uvodnih članaka i nekoliko vrlo korisnih dodataka, stoga ćemo se prvo osvrnuti na strukturu knjige.

Naslovnilistje na dvamajezicima:ruskomi avarskom. Naslovknjige na drugom titulnom listu na avarskome jeziku glasi: »МагІарул мацІальул гІандалазул диалекталъул словарь [maSarul mac'ałul Sandalazul dialektałul slowar]« (str. 3).

Na str. 4 - 6 nalazi se kratki opis rječnika na tri jezika: na ruskom (str. 4), na engleskom (str. 5) i na avarskom (str.6).

Knjiga započinje uvodnim člankom autora Gadži G. Gamzatova Jezični svijet Dagestana (o pitanju stanja i perspektiva leksikografskog osvajanja). 8 U članku se ističe misao da se o svestranoj i dubokoj proučenosti jezika može govoriti samo u slučaju ako su dovoljno opisani i istraženi njegovi dijalekti i govori. Takav rad na što potpunijem opisu leksičkog blaga pojedinih idioma ima iznimnu vrijednost, ne samo za daljnja jezikoslovna istraživanja (komparatistička i druga), već i za povijesna i etnološka istraživanja. Naime, mogli bi se potpuno neočekivano pojaviti novi, dosada nepoznati znanosti, podaci o vanjskim vezama dagestanskih jezika, što ima ogromno značenje za utvrđivanje, ne samo glotogeneza, već i etnogeneza Dagestanaca (str. 21).

Dalje slijedi Uvod na početku kojega Patimat Saidova piše o važnosti leksikografskoga proučavanja dijalekata općenito i naglašava da je dovoljno

7 Objavljeni su jedino rječnici koji u jednom izdanju obuhvaćaju sve dagestanske jezike ili čak jezike svih naroda Sjevernoga Kavkaza, pa je u njima između ostaloga zastupljen i leksik pojedinih avarskih dijalekata. Tako je godine 1988. i 1990. izišao rad A. E. Kibrika i S. V. Kodzasova Sopostavitel'noe izučenie dagestanskih jazykov ... (1988, 1990). Autori su opisali temeljni leksik, imenski (574 leksema) i glagolski (220 leksema), u usustavljenoj terminologiji i na ujednačen način, iznijeli su osnovne značajke gramatike odabranih idioma, a uz svaku su riječ naveli i osnovne morfološke oblike. Avarski jezik u radu zastupljen je govorom sela Čadakolob (gdje se govori ancuhski dijalekt južnog narječja avarskoga jezika). Još je jedna knjiga recentniji leksikografski rad koji obuhvaća velik broj jezika i dijalekata (92) naroda Sjevernoga Kavkaza različitoga genetskog podrijetla, rječnik Bernarda Comrie i Madzhida Khalilova (2010), koji sadržava 1300 rječničkih članaka. U tim se rječnicima, naravno, zbog opsežnosti ukupne građe nije moglo svaku riječ i njezinu semantiku leksikografski obraditi na uobičajen način u jednojezičnim i dvojezičnim rječnicima, a to im nije bila namjera, nego omogućavanje poredbenih i kontrastivnih istraživanja.

8 Jazykovoj mir Dagestana (k voprosu o sostojanii i perspektive leksikografičeskogo osvoenija), str. 7 - 24. 
potpuno i duboko istraživanje dijalekata i govora, uz opis svih njihovih osobitosti na različitim jezičnim razinama, od posebnoga značaja za dagestanske jezikejer oni nemaju drevnih spomenika pismenosti koji bi mogli pomoći pri rekonstruiranju povijesti pojedinih dagestanskih jezika (str. 25). ${ }^{9}$

U Uvodu se napominje da je autorica Rječnika Andalalkinja te da je izvorna govornica čohskoga govora. Njezin Rječnik sastavljen je na osnovi građe koju je sama autorica zabilježila kao izvorna govornica čohskog govora, a usporednu građu iz ostalih andalalskih govora prikupila je u selima svoga zavičaja Andalala od izvornih govornika. Tako se kao natuknica najčešće pojavljuje čohska riječ, dok se usporedna građa iz ostalih govora dodaje na kraju svakoga rječničkog članka u slučaju kada se fonemski, morfološki ili semantički razilazi od natuknice. Osim toga, u slučaju leksičkih dijalektizama, kao natuknice se pojavljuju i riječi iz drugih andalalskih govora.

U Uvodu je P. A. Saidova napomenula da je izrada rječnikā dijalektnoga leksika dagestanskih jezika odavno prisutan gorući problem i zahtjev vremena jer u suvremenim uvjetima dolazi do snažnoga utjecaja standarda na dijalekte i govore, a odlaskom predstavnika starije generacije nepovratno se gubi iznimno vrijedna nezabilježena leksička građa vezana uz način života i svakidašnjicu, materijalnu kulturu i duhovni život autohtonih stanovnika planina (str. 25).

Dalje slijedi Predgovor, ${ }^{10}$ u kojem je P. A. Saidova iznijela osnovne podatke o andalalskom dijalektu i njegovim govorima. Prije svega, napominje da je poznati proučavatelj avarskoga jezika i njegovih dijalekata Š. I. Mikailov u andalalskom dijalektu razlučio deset govora prema njihovim fonetskim, morfološkimileksičkim osobitostima (Mikailov1959:176). Autorica je navela popis tih govora, a uz svaki su

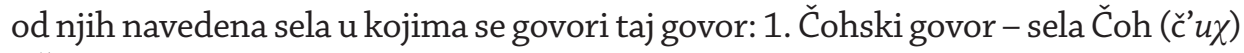

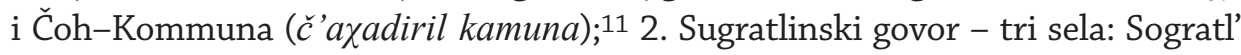
(surrat:) idr.; 3. Rugžinski - devet sela: s. Rugudža (rusžab)i dr., 4. Saltinski - sedam

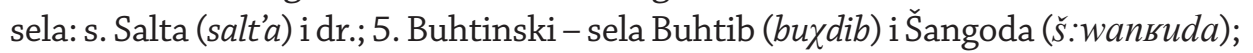
6. Kegerski - selo Keger (k’ohorib); 7. Kujadinski - četiri sela: Agada (arada) i dr.; 8.

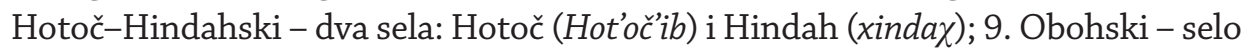

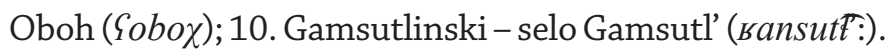

Andalalski dijalekt govore stanovnici ukupno 33 naselja, koja pripadaju u Gunibsku i Gergebilsku regiju Dagestana. Osim toga, velik broj Andalalaca danas stanuje u selima nizinskoga dijela Dagestana i u dagestanskim gradovima. Broj Andalalaca je, prema podacima 2016. godine, 26506 ljudi (str. 27).12 Autorica je

$9 \quad$ Vvedenie, str. $25-26$.

10 Predislovie (str. $27-28$ ).

11 U svom je popisu autorica ruskom nazivu sela dodala i nazive na avarskom. Ovdje prenosimo ruske nazive u transliteraciji, dok avarske nazive navodimo u transkripciji (u kurzivu). Ako se pojedini govor govori samo u jednom ili dva sela, onda ćemo popis sela navesti u potpunosti, a ako u više od dva sela, onda ćemo od punog popisa navesti samo jedan primjer.

12 Ovdje nije ubrojeno stanovništvo koje je preselilo u razne gradove i sela u nizinskim krajevima Dagestana. 
također napomenula da svi Andalalci govore i ruski jezik, a samo djeca predškolske dobi (koja žive u svom zavičaju, Andalalu) govore jedino andalalski dijalekt.

Dalje je P. A. Saidova iznijela popis sela koja čine područje Andalala uz podatak o broju stanovnika u svakome od njih (str. 28). Kao primjer navest ćemo nekoliko

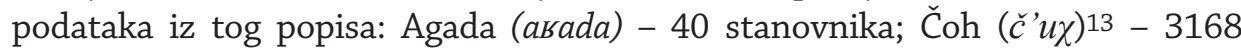

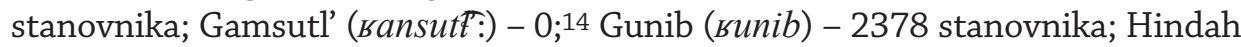

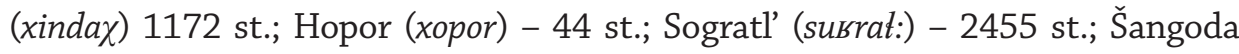
$(\check{s}$ : wansuda -551 st. itd.

Nakon Predgovora slijedi veliki i za korisnike Rječnika iznimno važan članak O ustroju rječnika, ${ }^{15}$ u kojem je razjašnjena struktura rječničkoga članka te načini razrade značenja riječi. Također, u ovom su članku izložene napomene o načinu predstavljanja vrsta riječi i njihovih oblika.

U Popisu kratica ${ }^{16}$ navode se prvo kratice za govore andalalskoga dijalekta, a iza toga slijede kratice za gramatičke i druge termine. Uvodni dio Rječnika završava azbučnim redom prema kojemu su poredane natuknice Rječnika.17

Na kraju knjige, iza samoga Rječnika18 priložena su četiri vrijedna dodatka. Prvi je od njih Rusko-andalalsko kazalo, koje je vrlo važno za korisnike knjige, ${ }^{19}$ jer olakšava služenje rječnikom i omogućava pretraživanje knjige prema ruskoj riječi.

Slijede dva onomastička dijela. Osobitu je pozornost Patimat Saidova usmjerila na proučavanje toponimijeimikrotoponimije Andalala, teje to prvi onomastički dio Rječnika koji sadržava andalalsko toponimijsko nazivlje. ${ }^{20}$ Nazivlje je usustavljeno prema naseljima, dakle poslije naziva pojedinoga sela slijedi popis mikrotoponima poredan azbučnim redom. Prvo se navodi mikrotoponim, iza toga u zagradama slijedi ekvivalent na ruskom jeziku, a zatim prijevod na ruski (ako se izdvaja neko značenje), i na kraju se u kurzivu dodaje podatak o vrsti toponima na koji se on

13 Prvo se navodi naziv sela na ruskom (transliteracija), a zatim je, u zagradama, isti toponim na avarskom (transkripcija).

14 Danas je Gamsutl napušteno selo, iako je još 2000. godine u njemu stanovalo oko dvije stotine ljudi.

15 O postroenii slovarja, str. 29 - 39.

16 Spisokuslovnyh sokraščenij, str. $40-42$.

17 Alfavit, str. 43. Azbuka (na osnovi ruske ćirilice) prilagođena avarskomu fonetskom sustavu uključuje 52 slova, a velik se broj slova objašnjava velikim brojem suglasnika u avarskom i inače dagestanskim jezicima, usp. rečeno o lakskom suglasničkom sustavu u: Gadžijeva (2019: 269, bilješka 18). Opisanom su sustavu i načelima lakske grafije dovoljno bliski i avarski. Mnoga su slova dodana ćirilskoj ruskoj azbuci, to su različite kombinacije slova, većinom ćirilskih. Rabi se »štapić“ (latinično verzalno slovo I) iza nekih slova, najčešće za oznaku abruptivnosti (usput rečeno, nije uvijek u ovoj inačici azbuke abruptivnost označena sa "štapićem«, a i »štapić« ne služi jedino za označavanje abruptivnosti). Od ukupno 52 slova - 19 su dvoslovi, a postoje i četiri grafema od četiri znaka. Do tih »dugih« četveroslovnih grafema dolazi u onim slučajevima kada je odgovarajući negeminirani (slabi) fonem označen dvoslovom. Navodimo azbučni red ovdje dodajući svakom grafemu transkripciju: a [a], б [b], в [w], г [g], гъ [в], гь [h], гІ [乌], д [d], e [e, je], ж [ž], з [z], и [i], й [j], к [k], кк

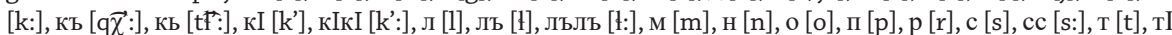
$\left[t^{\prime}\right], y[u], x[\chi], x x[\chi:]$, хъ $[q \widehat{\chi}:]$, хь $[\mathrm{x}], \mathrm{xI}[\mathrm{H}]$ (kod grafema xI »štapić« ne služi kao oznaka abruptivnosti, taj grafem označava frikativni bezvučni faringal), ц [c], цц [c:], цI [c'], цІцI [c':], ч [č], чч [č:], чI [č'], чIчI [č':], ш [š], щ [š:], ъ [?], э [е], ю [ju], я [ja].

18 Slovar', str. $44-556$.

19 Russko-andalal'skijukazatel', str. 557-652.

20 Toponimičeskie nazvanija, str. $653-685$. 
odnosi, primjerice, oranica, područje, kvart u naselju, pašnjak, livada, brdo, klanac, stijena, brijeg, obronak, izvor, šuma, groblje, jezero, pećina, tor, farma, zaselak, močvara itd. Navest ćemo ovdje nekoliko primjera redaka iz popisa toponima:

selo Čoh: imamuHandilrahla(Имамухандил рахла)-около(дома)Имамухама - двор, родник ('pokraj (kuće) Imamuhama - dvorište, izvor') c':rorab ic: (Ццорораб ицц) - студеный родник ('hladan izvor') č:e९erab nохо (Чеэраб нохо) - черная пещчера ('crna pećina') gadajda (Гадайда) - квартал ('kvart u naselju')

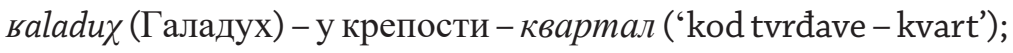

selo Kudali: čujal t’amineb guH (Чуял таминеб гух) - холм, где проводятся конные скачки ('brežuljak, pokraj kojega se održavaju konjske utrke’).

Iza toponimijskoga slijedi drugi onomastički dio - antroponimijski, 21 u kojem su nabrojena osobna imena koja se susreću kod Andalalaca. U ovom dijelu za svako andalalsko naselje posebno su azbučnim redom popisana prvo muška, a zatim ženska imena.

Zatim slijedi vrlo vrijedan dio knjige Kratki gramatički pregled andalalskoga dijalekta 22 koji je podijeljen na sljedeća poglavlja: Fonetika, Morfologija, Kratki podaci o sintaksi i Leksik. Opis svake gramatičke kategorije andalalskoga dijalekta redovito je popraćen bilježenjem svih razlika u usporedbi sa standardnim avarskim jezikom. Primjerice, kod opisa sklonidbeličnih zamjenica autoricaje dodatno navela podatke o tome koji padežni nastavci predstavljaju razliku u odnosu na standardni jezik. Specifični su nastavci u ergativu i u dativu, te su stoga za te padeže, radi usporedbe, navedeni i nastavci avarskoga standardnogjezika (str. 757). Budući da je za osnovu gramatičkoga opisa uzeta, isto kao i u rječniku, građa čohskoga govora, na kraju opisa svake gramatičke kategorije P. A. Saidova je iznijela razlike u govorima, ukoliko postoje. Tako su, primjerice, zabilježeni specifični nastavci imperativa u obohskom i kujadinskom govoru.

$\mathrm{Na}$ kraju rada naveden je popis literature citirane u uvodnim člancima i u gramatičkom pregledu. ${ }^{23} \mathrm{Iz}$ tog se popisa može steći, između ostalog, i uvid u postojeće rječnike, ne samo avarskoga jezika, već i andijskih i cezijskih jezika (čamalinskoga, karatinskoga, tindinskoga, bagvalinskoga, ahvahskoga, godoberinskoga, bežtinskoga), kao i gramatičke opise tih jezika te dijalekata i govora avarskoga jezika.

Knjiga završava bilješkom o autorici koju potpisuje urednik knjige Madzhid Sh. Khalilov, a naslovljena je Doprinos proučavanju dagestanskih jezika. ${ }^{24}$ Taj članak

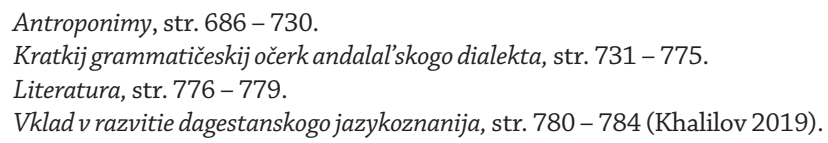


opisuje usmjerenja znanstvenoga rada Patimat Saidove, kao i postignute rezultate, odnosno najvažnije objavljene radove.

Za osnovu andalalskoga rječnika je u cjelini, kao i pojedinih rječničkih članaka, uzet leksik čohskoga govora. Čohska riječ stoji na početku velike većine rječničkih članaka, a otisnuta je velikim slovima. Poslije morfoloških podataka o riječi i prijevoda na ruski te ilustrativne građe, na kraju rječničkoga članka uz kratice za ostale andalalske govore (primjerice: keg. kegerski, buh. buhtinski itd.) nabrojene su inačice drugih govora u slučajevima raznolikosti, tj. kada su njima svojstvene fonetske, morfološke ili semantičke razlike u odnosu na čohski govor:

МАРГУ́ ... веретено ... куд. марго́, суг. мергу́, ост. мерго́25

ЧИРА́ХХ ... лампа, светильник ... бух., кег., куд. чира́хъ 26

БЕ́РЦИНАБ ... красивый ... куд. бе́рценаб27

Leksičke se inačice navode kao zasebna natuknica uz uputu na glavnu natukni$\mathrm{cu}$, tj. na odgovarajući leksem u čohskom govoru, na primjer:

КІАЛИ́КІУЧІ бух.; см. ма́нгуру28

МА́НГУРУ ... бабочка ... кд. гьа́лакІач, куд. гьалбу́ттин, руг. гьа́ликІач, суz. те́шо, сал. хІа́никІач, буx. кІали́кІучI, хин. гІа́ликІач, кег. хІа́ликІач29

Ako u rječničkom članku nisu zabilježeni podatci o ostalim andalalskim govorima to znači da kod dotične riječi nema raznolikosti u govorima.

Tvorba gramatičkih oblika kod mnogih je riječi popraćena ablautom. Osnovni oblici takvih riječi navode se kao zasebne natuknice uz uputu na glavnu:

БАЧА́Л мН. от бече́30 (str. 96)

БЕЧЕ́ (бичи́д, бичи́л, бача́л) ... теленок ...31 (str. 113)

Poslije osnovnih gramatičkih oblika navodi se prijevod natuknice na ruski jezik, a potom slijedi ilustrativna građa - kolokacije, sintagme i rečenične potvrde. Ako u ruskom jeziku ne postoji potpuna istoznačnica, uzima se riječ bliskoga ili šireg značenja, a u zagradama se dodaje pojašnjenje, primjerice:

25 margú ... 'vreteno' ... kudalinski margó, sugratlinski mergú, ostali mergó.

26 čirá $\chi$ 'lampa, svjetiljka' ... buhtinski, kegerski, kudalinski čiráq $\chi$ :.

27 bércinab ... 'lijep' ... kudalinski bércenab.

28 k'alík'uč' buhtinski; v. mánguru.

29 mánguru ... 'leptir' ... kujadinski hálak'ač, kudalinski halbút:in, rugžinski hálik'ač, sugratlinski téšo, saltinski Hánik'ač, buhtinski k'alík'uč', hindahski Sálik'ač, kegerski Hálik'ač.

30 bačál množina od bečé.

31 bečé (bičíd, bičíl, bačál) ... 'tele' ... 
МИГЬИ́ЛГІЕЛ ... сторож (охраняющчий посевы и луга) ...32

Frazemi se donose iza znaka romb $(\diamond)$, na primjer:

ГЬОЦІЦО́ ... мед; ... $\diamond$ гьуццульль ццан баде испортить (букв. в мед соль сыпать) ...33

Poslovice i uzrečice unose se bez znaka $\oslash$, uz odrednicu posl., pogov. (пословица 'poslovica', поговорка 'uzrečica'). Navodi se odgovarajuća ruska poslovica, a u zagradama doslovni prijevod:

ГІИЛЛА́ ... причина ... кІудаб гІилла серьезная причина; гІилла батте найти причину; гІилла гьаде узнать причину; гІилла гьечІаб беспричинный, необоснованный; гІилла гьечІуго без всякой причины; гІилла гьечІуго гІучІги багъарамаро посл. нет дыма без огня (букв. без причины и соломинка не шевелится) $)^{34}$

Nazivi kućnih potrepština, poljoprivrednoga alata i drugih realija koje nemaju istoznačnica u ruskom jeziku preneseni su na ruski u najbližem mogućem fonemskom obliku, a značenje je pojašnjeno u zagradama (navedeno u kurzivu):

УРБЕ́Ч (-ид, -ил) урбеч (лакомство из молотого льняного семени с маслом и медом); урбеч гьубуде приготовить урбеч; ... суг. хьон, кд. льоло́хьон, хин., руг. льоло́хьан, бух. хьом, куд., сал. льоло́хьодол нагь $^{35}$

Pojašnjenja u zagradama kurzivom dodaju se i poslije prijevoda na ruski kako bi se definiralo uže značenje, na primjer:

ГИБИ́ ... большой горшок (керамический, для молочных продуктов, для хранения зерна и других продуктов) $)^{36}$

АЛА́ ... корзина (из коры дерева, для ниток, шерсти и других предметов рукоделия $)^{37}$...

Spomenut ćemo samo neke pojedinosti o prikazivanju pojedinih vrsta riječi $\mathrm{u}$ rječniku. Imenice se donose u nominativu, a iza natuknice u oblim zagradama navode se sufiksi padežnih oblika - ergativa, genitiva i nominativa množine:

32 misílSel ... 'čuvar (koji čuva polja, usjeve i livade)'.

33 hoc':ó 'med'; $\diamond$ huc':ul: c':an bade 'pokvariti' (dosl. u med nasipati sol) ...

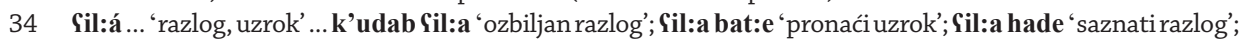

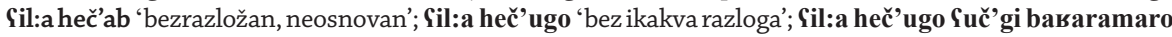
posl. 'nema dima bez vatre' (dosl. bez razloga ni slamčica se ne miče).

35 urbéč (-id, -il) 'urbeč' (poslastica od mljevenih lanenih sjemenki pripremljenih s maslacem i medom); urbeč hubude 'pripremiti urbeč'; sugratlinski xon, kujadinski lolóxon, hindahski, rugžinski lolóxan, buhtinski xom, kudalinski, saltinski łolóxodol nah.

36 gibí ... 'veliki lonac (glineni, za mliječne proizvode, za čuvanje žitarica i dr.)'.

37 alá ... 'košara' (od kore drveta, za konce, vunu i razne predmete za šivanje, pletenje, vez i sličan ručni rad) ... 
БАГЬА́ (-Д, -дул, -би) цена ${ }^{38} \ldots$

Pridjevi se navode u obliku trećega gramatičkog razreda39:

ЦІЦІОДО́РАБ умный, сообразительный; цІцІодораб гьемер умный ребенок; цІцІодорав вас смышленый мальчик 40 ...

У́ХАБ низкий; ухаб остол низкий стол 41 ...

БА́ЦІЦІАДАБ 1) чистый; ... бацІцІадаб гъадари чистая тарелка; ... 4) невинный, невиновный, безвинный; вацІцІадав чи безвинный человек; 5) аккуратный, опрятный, чистоплотный; яцІцІадай адан чистоплотная женщина; женщина с честью и с совестью; $\diamond$ вацІцІадав абдал разг. круглый дурак, глупец (букв. чистый дурак) 42

Kod zamjenica autorica Rječnika navodi gramatičku odrednicu vrste zamjenice u kurzivu: lične, posvojne, povratne, pokazne, upitne i niječne. Među pokaznim zamjenicama neki imaju specifično značenje, tako da ne postoje istovrijednice u ruskom jeziku. Kod takvih je zamjenica autorica u zagradama kurzivom navela pojašnjenje. Primjerice, kod ukazivanja na udaljene predmete provodi se razlikovanje značenja pokaznih zamjenica s obzirom na relativnu visinu na kojoj se nalazi predmet, tj. nalazi li se on na istoj razini kao i govornik, iznad te razine ili ispod:

ГЬИ́ГЬАБ мест. указ. тот, та, то ... (указывает на то, что находится ниже говорящего и на виду) ... гьигьаб нухІла дида бурухь батана на той дороге я змею нашла... 43

Kao nastavak istoga značenjskog sustava, pokazna zamjenica hídab označuje ono što se nalazi na istoj razini kao govornik (primjerice, hídab ex 'ona knjiga'), a hílab označuje ono što se nalazi na razini iznad govornika (hílabt ți:uri ‘ona stijena').

38 bahá $(-\mathrm{d},-$ dul, - bi) 'cijena' ...

39 U andalalskom dijalektu, kao i inače u avarskom jeziku, sve su imenice raspodijeljene u tri gramatička razreda: u prvi razred spadaju sve imenice koje označavaju muškarce (dakle, sa značenjima, primjerice, 'muškarac', 'otac', 'sin', 'brat', 'učitelj', 'časnik' itd.); imenice koje označavaju žene čine drugi razred, dok trećem razredu pripadaju sve ostale imenice (imenica 'dijete', životinje, predmeti, pojave, razne imenice apstraktnoga značenja itd.). Kod imenica razred nije izražen, ali kod pridjeva je gramatička veza s imenicom izražena putem razredskoga pokazatelja, koji se nalazi na početku i na kraju riječi ili samo na kraju riječi. Razredski je pokazatelj 1. razreda $w, 2$. razreda j, a 3. razreda $b$. Primjerice, bórk'adab 'visoki'; bork'adab q $\mathbf{q}$ :e 'visoki zid'; work'adaw či 'visoki muškarac' ...

40 c':odórab 'pametan, inteligentan, dosjetljiv, bistar'; c':odorab hemer 'pametno dijete'; c':odoraw was 'pametan dječak' ...

41 úxab 'niski'; ưab ostol 'niski stol'...

42 bác':adab 1) čisti; ... bac':adab sadari 'čisti tanjur'; ... 4) nevin, nedužan; wac':adaw či 'nedužan čovjek'; 5) uredan, čist; jac':adaj adan 'uredna žena'; 'časna žena'; $\diamond$ wac':adaw abdal razg. 'potpuna budala' (dosl. ‘čista budala').

43 hírab pokazna zamjenica 'onaj, ona, ono' (označuje predmet koji se nalazi ispod razine govornika te vidljiv je); ... hikab nuHla dida burux batana 'na onoj cesti našla sam zmiju' ... 
Za glagole natuknice se navode u infinitivnom obliku, iza kojeg u oblim zagradama slijede nastavci osnovnih glagolskih oblika (prezenta općeg, 44 futura, aorista $\mathrm{i}$ imperativa):

КИ́КДУБ/УДЕ (-ума, -ула, -уна, -е) понуд. уменьшать, уменьшить ...; умугь кикдубуде уменьшить размер шубы 45

Na kraju pregleda ustroja rječničkog članka navodimo dva rječnička članka u potpunosti:

ЦІЦУУ́ТІ/ГЪЕЖ (-гъажалд, -гьажа́лдул, -гьу́ждул) анат. локоть; унтараб цІцІутІгъеж больной локоть; цІцІутІгъажалд тункде толкнуть локтем; кд., куд. гІу́нкІрукь буx. зенкІе́л, $p y z$. зонкІло, $c y z$. хутро́, сал. гІо́нкърокь, хин. зокІно́гъеж, кег. зокІно 46

КЪА́ДЕНАХА нареч. после полудня; къаденаха хІалтІи льльугІана после полудня работу завершили; куд., сал., бух. къа́денахъе 47

Od leksičkih osobitosti andalalskoga dijalekta ovom ćemo prilikom ukratko spomenuti samo one koje su vezane uz podrijetlo leksema. S obzirom na podrijetlo, leksik andalalskoga dijalekta, kao i svakoga dagestanskog idioma, obuhvaća, uz izvorne dagestanske riječi, posuđenice raznoga podrijetla: 1) znatan broj orijentalizama, tj. riječi arapskoga, turskog (ili turkijskoga) i perzijskoga podrijetla; 2) druga vrsta posuđenica (iz kasnijega razdoblja) su rusizmi i riječi iz europskih jezika, koje su ušle u avarski i ostale dagestanske jezike preko ruskoga. Brojni orijentalizmi u dagestanskim jezicima, kao i rusizmi, govore o dodirima i utjecajima naroda i kultura kroz povijest, te su neizostavan dio leksičkoga blaga andalalskoga dijalekta i avarskoga jezika općenito. 48 Ovdje ćemo navesti samo neke primjere orijentaliza-

44 Autorica za prezent opći rabi termin 'opće vrijeme' (»общее время«), slijedeći određenu tradiciju jer se taj termin susreće i u gramatikama drugih stručnjaka za avarski jezik (Saidov 1967: 779, Madieva 2000: 56 i dr.). Ovdje se pridržavamo termina 'prezent opći' koji rabi Zulaykhat M. Mallaeva u svojoj knjizi specijalno posvećenoj glagolskoj morfologiji avarskoga jezika - Glagol avarskogo jazyka: struktura, semantika, funkcii (2012: 108), a taj termin također ima već dužu tradiciju, na primjer, rabi se u radu Alekseev 1988: 45. Osim toga, još u gramatičkom opisu P. K. Uslara upotrijebljen je vrlo bliski termin za taj glagolski oblik: 'prezent neodređeni' (»настоящее неопределенное«) (1889: 201).

45 kíkdub/ude (-uma, -ula, -una, -e) kauzativ 'smanjiti, smanjivati, umanjiti' ...; umur kikdubude 'smanjiti veličinu bunde', 'smanjiti bundu'.

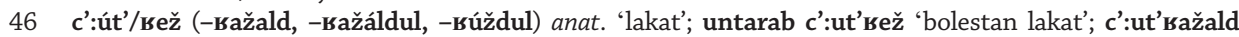
tunkde 'gurnuti laktom'; kujadinski, kudalinski Súnk'rutł':, buhtinski zenk'él, rugžinski zonk'ló, sugratlinski

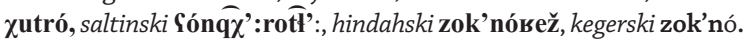

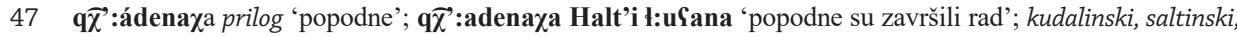
buhtinski $\mathbf{q} \widehat{\chi}$ :ádenaq $\widehat{\chi}: e$.

48 U vezi s tim usp. mišljenje Krunoslava Puškara, u kojem se dobro ogleda uloga i mjesto posuđenica u jezičnom sustavu pojedinog govora: »Treba napomenuti kako se pri odabiru građe ne bi trebalo povoditi načelom rječnika »čistoga« govora u kojem se ne bi pridavalo mnogo pažnje posuđenicama kojima pojedini govor zapravo obiluje. Takav bi pristup zaista bio začuđujući jer su posuđenice iz bilo kojeg vremenskog perioda rezultat dodira ne samo dvaju različitih jezičnih sustava nego i dviju kultura čije se posljedice mogu osjetiti na svim razinama. Uklonimo li tako iz rječnika brojne germanizme i hungarizme za koje čak ne postoje »čisti« dijalekatni ekvivalenti, nadaleko osiromašujemo taj rječnik i njegovu povijesnu, kulturnu i, prije svega, sociolingvističku obavijesnost« (Puškar 2015: 146). 
ma iz Rječnika andalalskoga dijalekta. Među njima će hrvatski čitatelji prepoznati mnoge riječi jer su one u prošlosti iz istih izvora dospjele i u hrvatski jezik, ${ }^{49}$ kat-

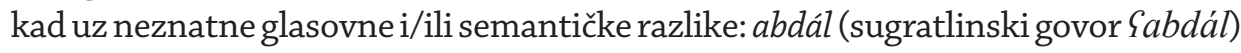
'lud, budala'50, alát 'alat'; čakár 'šećer'; dilmáž 'prevoditelj';51 saránpil 'klinčić;'52

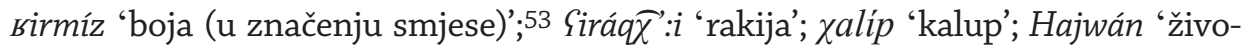
tinja'; išán 'nišan'; majdán 'trg, ravan teren';54 majmún 'majmun'; pamá 'pamuk'; s:apún 'sapun'; s:aSát 'sat', (u oba značenja: 1. vremenska jedinica, 2. sprava za mjerenje vremena); tarbá 'torba'; t’amúr 'tambura (žičano glazbalo)'; top 'top (artiljerijsko oružje)'; tukán 'trgovina, kiosk';55 tušmán 'neprijatelj';56 tut 'dud, murva'; waq $\vec{\chi}: p u ́$ 'vakuf'; žip (buhtinski govor) 'džep'; žurábal 'vrsta pletene obuće';57 žurıán (rugžinski govor wirsán, kudalinski i hindahskijursán) 'poplun, pokrivač’58 itd.

Rječnik andalalskoga dijalekta sadrži brojne zanimljive primjere koji odražavaju osebujnost svjetonazora, duhovne i materijalne kulture naroda, primjerice, leksik vezan uz religiju, rodbinsko nazivlje,59 nazivlje iz područja stočarstva i prehrambenih proizvoda (posebice mliječnih proizvoda), nazivlje za posuđe itd. Kao ilustrativne primjere autorica je navela ne samo brojne sintagme i kolokacije, već i rečenične potvrde, i frazeme zanimljivoga sadržaja. S time u vezi navest ćemo mišljenje Đure Blažeke o važnosti strpljivoga odabira rečeničnih potvrda za dijalektni rječnik: ako se rečenične potvrde pažljivo biraju, »rječnik prestaje biti samo ogledalo jezičnih sustava u strukturalističkom smislu, veći prikaz manje ili više osviještenih normi, uzora, vrijednosti i očekivanja u antropološkom smislu. <...> Najbolja je varijanta kad se uz »normalnu« rečeničnu potvrdu za neki leksem pronađe i frazem, no poželjno je da i ta "normalna« rečenična potvrda bude što zanimljivija« (2008: 151). Patimat Saidova je u svojoj knjizi uspjela uplesti duh andalalskoga svakodnevnog govora u tkivo rječničkih članaka. Ilustrativni primjeri, rečenične potvrde njezina rječnika prikazuju raznovrsne pojave, činjenice te okolnosti svakodnevnoga života u seoskom području u planinama s namjerom

49 Među tim orijentalizmima u hrvatskom jeziku neki su prihvaćeni kao standardne riječi, dok su drugi stilski obilježene kao razgovorne; neki se od njih u rječnicima navode uz posebnu odrednicu kao regionalne ili stručne (povijesno nazivlje i dr.).

50 Usp. hrvatski budala. Ovdje u bilješci navodim odgovarajuću hrvatsku posuđenicu istoga podrijetla samo u slučaju bitnijih fonemskih razlika koje čine riječ manje prepoznatljivom.

51 Usp. hrvatski tumač.

52 Usp. hrvatski karanfil.

53 Usp. hrvatskigrimiz.

54 Usp. hrvatski regionalni i povijesni izraz majdan u značenju 1) 'rudnik', 2) 'kamenolom'.

55 Usp. hrvatski regionalizam dućan.

56 Usp. hrvatski dušmanin, dušman.

57 Usp. hrvatski čarape.

58 Usp. hrvatski regionalizam jorgan.

59 O relativnoj iznijansiranosti rodbinskoga nazivlja govori primjer: postoji poseban leksem ne samo za pojmove 'sestra' i 'sestrična', već i za daljnji stupanj rodbinske veze, npr. jac: 'sestra'; jác:aSal 'sestrična'; c:onóSal - 'kći ili sin majčina ili očeva bratića (ili sestrične)'. 
približavanja andalalske, a time i šire, avarske narodne kulture čitatelju, kojem je ona nepoznata, i istovremeno pridonijeti njezinom očuvanju za naraštaje Andalala za koje bi to sve moglo postati samo dio prošlosti. Na stranicama rječnika P. Saidova se potrudila u što većoj mjeri odraziti i suvremeni za nju kulturni život, njegove značajne pojave. Za ilustraciju navest ćemo ovdje nekoliko primjera:

КЕРЧІ (корчІо́д, корчІо́л, ку́рчІдул) 1) песня, пение; ... Муил курчІдул киназуйго рокьама песни Муи 60 любят все ...61

ПАНА': ПАНА' ГЬУБ/УДЕ (-ума, -ула, -уна, -е) пленить, очаровать; ... Муил курчІдуз адамал пана гьурума песни Муи очаровывают 62

ЭХХЕ́ДАГІАН ... нареч. выше, повыше; эххедагІан нижер хІур буго повыше находится наша пашня63 ...

ХОСО́ЛО нареч. осенью; ... хосоло гІи гьаргІибе бигьама осенью отары возвращаются на плоскость 64 ...

РА́КІБЕК/ДЕ (-ама, -ла, -ана) опечалиться; грустить, тосковать; эбел гьечІуни, гьамазул ракІбекама отсутствие матери печалит детей65

РИИ́ДАЛ нареч. летом; ... риидал бурухь бихьарав хосоло гІарщисса хІенкъама посл. тот, кто летом змею увидел, осенью и веревки боится; ...66

АДА́Б ...вежливость, учтивость, приличие, уважение; ... гІессеназул адаб гьубе, к'удазул хІурмат гьубе посл. относись с уважением к младшим, с почтением к старшим 67

Rječnik andalalskoga dijalekta avarskog jezika sadrži vrlo pažljivo zabilježenu leksičku građu andalalskih govora, a izradila ga je jezikoslovka za koju je Andalal bio njezin zavičaj i koja je bila stručnjak za dagestanske jezike te za dijalektologiju svoga materinskog, avarskoga jezika.

60 Mui Gasanova (1930-2014) je poznata dagestanska pjevačica podrijetlom iz sela Čoh Gunibske regije. Uvelike je doprinijela očuvanju dagestanske tradicionalne narodne glazbene umjetnosti i smatra se najboljom avarskom pjevačicom 20. stoljeća.

61 kerč' (korčód, korč’ól, kúrč’dul) ... 'pjesma, pjevanje' ... Muil kurč'dul kinazujgo rotFł:ama 'pjesme Mui svi vole'.

62 paná: paná hub/ude (-uma, -ula, -una, -e) 'očarati, oduševiti' muil kurč’duz adamal pana huruma 'pjesme Mui očaravaju ljude'.

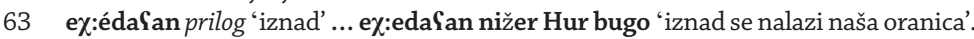

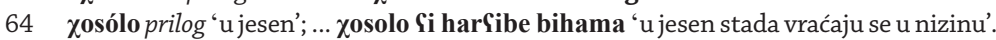

65 rák'bek/de (-ama, -la, -ana) tugovati, rastužiti se, čeznuti; ebel heč’uni, hamazul rak'bekama 'odsutnost majke rastužuje djecu (kada majke nema, djeca tuguju za njom)'.

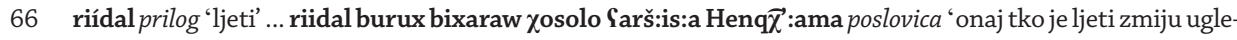
dao, u jesen se i užeta boji'.

67 adáb ... 'ljubaznost, odgojenost, obzirnost, poštovanje' Ses:enazul adab hube, k'udazul Hurmat hube poslovica 'Odnosi se uz cijenjenje (uvažavanje, obzirnost, ljubaznost) prema mlađima, uz poštovanje prema starijima'. 
Patimat Saidova je u svom rječniku andalalskoga dijalekta ostvarila pionirski pothvat prikazivanja svijeta andalalske riječi, i to u cjelokupnoj raznovrsnosti mjesnih govora. Budući da se takav dijalektni rječnik jednog dagestanskog jezika, s uključenjem građe svih govora izrađivao prviput, autoricaje razradilai metodološka rješenja za svoj rječnik, uspješno odredila pristup i načela uključenja građe različitih govora, način predstavljanja svih podataka u rječniku. Dakle, prikazani rad, ne samo da predstavlja prvi i uspješan pokušaj prikupljanja maksimalno potpunoga leksika andalalskoga dijalekta, već on ujedno prvi put u dagestanskoj teoretskoj i metodologijskoj leksikografiji predlaže i primjenjuje načela sastavljanja rječnika mjesnih govora pojedinoga dijalekta jednoga od dagestanskih jezika, i to na visokoj znanstvenoj razini, pouzdano i stručno.

Stoga valja naglasiti da će ovaj Rječnik biti od velike vrijednosti za dijalektnu leksikologiju i leksikografiju avarskoga jezika, za proučavanje povijesti avarskoga jezika a ujedno će postati poticaj za nove dijalektološke radove u dagestanskom jezikoslovlju, kao i za daljnja poredbena istraživanja avarsko-andijskih te cezijskih, drugih dagestanskih i šire - kavkaskih jezika. Rječnik će poslužiti ne samo jezikoslovcima, nego i stručnjacima drugih humanističkih usmjerenja - etnolozima i folkloristima, povjesničarima i antropolozima.

Budući da je danas dio dijalektnoga leksika, zbog utjecaja standarda, sve manje u uporabi, Rječnik će biti od neprocjenjive vrijednosti za Andalalce, kojima će pomoći u očuvanju zavičajnoga izraza te dubljem znanju i razumijevanju materinskoga govora u svim njegovim ostvarenjima, u njegovoj varijantnosti - i na taj će način rječnik dati važan doprinos avarskoj kulturi općenito. 68

Sofija Gadžijeva

\section{Literatura69}

Alekseev, Mikhail E. (1988). Sravnitel'no-istoričeskaja morfologija avaro-andijskih jazykov. Moskva: Nauka.

Alekseev, Mikhail E. (1998). Avarskij jazyk. Jazyki mira: Kavkazskie jazyki. Moskva: Academia, 204-217.

Alekseev, Mikhail E., Said Z. Alikhanov, Boris M. Ataev, Magomed A. Магомедов, Маgomed I. Magomedov, Gjulzhagan I. Madieva, Patimat A. Saidova, Dzhalil S. Samedov (2014). Sovremennyj avarskijjazyk. 2. izdanje, dopunjeno. Mahačkala: IJaLI DNC RAN, ALEF.

68 U svezi s time, podsjetit ćemo na zanimljiva i vrijedna razmišljanja o potrebi rječnika kajkavskih dijalekata i mjesnih govora potkalničkoga Prigorja, izložena u članku Krunoslava Puškara, gdje autor između ostalog napominje: »Rječnik pojedinoga mjesnog govora ili više njih može biti poticaj za bolje njegovanje lokalne kajkavske riječi, čime se ostvaruje i bolji osjećaj lokalnog identiteta« (2015: 141).

69 Kratice u popisu literature: IJaLI DNC RAN = Institut jazyka, literatury i iskusstva imeni Gamzata Cadasy Dagestanskogo naučnogo centra Rossijskoj akademii nauk; DFIC RAN = Dagestanskij federal'nyj issledovatel'skij centr Rossijskoj akademii nauk (novi naziv bivšega DNC RAN, od 2019. godine). 
Blažeka, Đuro. 2008. Koncepcija rječnika međimurskog dijalekta. Hrvatski dijalektološki zbornik, knj. 14, 137-157.

Comrie, Bernard i Madzhid Khalilov (2010). The Dictionary of languages and dialects of the peoples of the Northern Caucasus: Comparison of the basic lexicon (Languages and Dialects of peoples of Republic of Daghestan, Ingush Republic, Republic of North Ossetia-Alania, Chechen Republic and the Nakh-Daghestanian peoples of Azerbaijan and Georgia). Leipzig - Makhachkala: Max Plank Institute for Evolutionary Anthropology.

Gadžijeva, Sofija. 2019. Isa Halidovič Abdullaev (2018) Laksko-russkij slovar'. IJaLI DNC RAN, ALEF, Mahačkala. Suvremena lingvistika. 2019. 45/88, 265-278.

Khalilov, Madzhid Sh. (2019). Vklad v razvitie dagestanskogo jazykoznanija (K 85-letiju so dnja roždenija P. A. Saidovoj). Patimat A. Saidova. Slovar' andalal'skogo dialekta avarskogo jazyka. Khalilov, Madzhid Sh. (ur.). Mahačkala: IJaLI DFIC RAN, ALEF, 780-784.

Kibrik, Aleksandr E. i Sandro V. Kodzasov (1988). Sopostavitel'noe izučenie dagestanskih jazykov. Glagol. Moskva: Izdatel'stvo Moskovskogo universiteta.

Kibrik, Aleksandr E. i Sandro V. Kodzasov (1990). Sopostavitel'noe izučenie dagestanskih jazykov. Imja. Fonetika. Moskva: Izdatel'stvo Moskovskogo universiteta.

Magomedov, Magomed I. (2008). Postigaja dušu slova. Saidova, PatimatA. Dialektologičeskij slovar' avarskogojazyka: okolo 8000 slov. Magomed I. Magomedov (ur.); IJaLI DNC RAN. Moskva: Nauka, 9-13.

Madieva, Gjulzhagan I. (2000). Avarskij jazyk. Gamzatov, Gadzhi G. (ur.). Jazyki Dagestana. Mahačkala-Moskva: Otdelenie literatury i jazyka RAN, IJaLI DNC RAN, Centr jazykov i kul'tur Severnoj Evrazii im. kn. N. S. Trubeckogo, 45-62.

Mallaeva, Zulaykhat M. (2012). Glagol avarskogo jazyka: struktura, semantika, funkcii. 2. izdanje. Mahačkala: IJaLI DNC RAN.

Mikailov, Šigabuddin I. (1959). Očerki avarskoj dialektologii. Moskva - Leningrad: Akademija nauk SSSR.

Puškar, Krunoslav (2015). Prijedlog koncepcije Rječnika govorâ potkalničkoga Prigorja. Cris, god. XVII., br. 1/2015., 141-154.

Russko-avarskij slovar': bolee 40000 slov. (2003). Alikhanov, Said Z. (ur.). Mahačkala: IJaLI DNC RAN.

Saidov, Magomedsajid D. (1967). Avarsko-russkij slovar'. Okolo 18000 slov. S priloženiem kratkogo grammatičeskogo očerka avarskogo jazyka M. Saidova. Moskva: Sovetskaja ènciklopedija.

Saidova, Patimat A. (1973). Godoberinskij jazyk: grammatičeskij očerk, teksty, slovar'. Mahačkala: Institut istorii, jazyka i literatury Dagestanskogo filiala Akademii nauk SSSR.

Saidova, Patimat A. (2006). Godoberinsko-russkij slovar'. Mahačkala: IJaLI DNC RAN.

Saidova, Patimat A. (2008). Dialektologičeskij slovar' avarskogo jazyka: okolo 8000 slov. Magomed I. Magomedov (ur.); IJaLI DNC RAN. Moskva: Nauka.

Saidova, Patimat A. i Magomed G. Abusov. (2012). Botlihsko-russkij slovar'. Mahačkala: IJaLI DNC RAN.

Uslar, Petr K. (1889). Ètnografija Kavkaza. Jazykoznanie. III. Avarskij jazyk. Tiflis: Izdanie Upravlenija Kavkazskogo Učebnogo Okruga. 